\title{
Effect of Frozen Storage on the Proteolytic and Rheological Properties of Soft Caprine Milk Cheese*
}

\author{
D. L. Van Hekken, ${ }^{1}$ M. H. Tunick, ${ }^{1}$ and Y. W. Park ${ }^{2}$ \\ ${ }^{1}$ Dairy Processing and Products Research Unit, Eastern Regional Research Center, USDA, ARS, Wyndmoor, PA 19038 \\ ${ }^{2}$ Agricultural Research Station, Fort Valley State University, Fort Valley, GA 31030
}

\begin{abstract}
Freezing and long-term frozen storage had minimal impact on the rheology and proteolysis of soft cheese made from caprine milk. Plain soft cheeses were obtained from a grade A goat dairy in Georgia and received 4 storage treatments: fresh refrigerated control (C), aged at $4^{\circ} \mathrm{C}$ for $28 \mathrm{~d}$; frozen control (FC), stored at $-20^{\circ} \mathrm{C}$ for $2 \mathrm{~d}$ before being thawed and aged in the same way as $\mathrm{C}$ cheese; and 3-mo frozen (3MF), or 6-mo frozen $(6 \mathrm{MF})$, stored at $-20^{\circ} \mathrm{C}$ for 3 or 6 mo before being thawed and aged. Soft cheeses had fragile textures that showed minimal change after freezing or over $28 \mathrm{~d}$ of aging at $4^{\circ} \mathrm{C}$. The only exceptions were the FC cheeses, which, after frozen storage and aging for $1 \mathrm{~d}$ at $4^{\circ} \mathrm{C}$, were significantly softer than the other cheeses, and less chewy than the other frozen cheeses. Moreover, after $28 \mathrm{~d}$ of aging at $4^{\circ} \mathrm{C}$, the $\mathrm{FC}$ cheeses tended to have the lowest viscoelastic values. Slight variation was noted in protein distribution among the storage treatment, although no significant proteolysis occurred during refrigerated aging. The creation and removal of ice crystals in the cheese matrix and the limited proteolysis of the caseins showed only slight impact on cheese texture, suggesting that frozen storage of soft cheeses may be possible for year-round supply with minimal loss of textural quality.
\end{abstract}

(Key words: caprine milk cheese, frozen storage, proteolysis, rheology)

Abbreviation key: $\mathbf{C}=$ refrigerated control, $\mathbf{F C}=$ frozen control, $\mathbf{G}^{\prime}=$ elastic modulus, $\mathbf{G}^{\prime \prime}=$ viscous modulus, $\mathbf{3 M F}=3$-mo frozen, $\mathbf{6 M F}=6$-mo frozen, $\mathbf{T P A}=$ texture profile analysis.

\section{INTRODUCTION}

The majority of caprine milk cheese manufactured and sold in the United States is fresh soft cheese. The

\footnotetext{
Received September 8, 2004.

Accepted February 28, 2005.

Corresponding author: Diane L. Van Hekken; e-mail: dvanhekken @errc.ars.usda.gov.

* Mention of a brand or firm name does not constitute an endorsement by the U.S. Department of Agriculture over others of a similar nature not mentioned.
}

availability of US manufactured cheese is limited by the short shelf life of the product and by the seasonal production of caprine milk. Freezing is one method of extending shelf life and availability of highly perishable foods, but has mixed effects on cheeses. Freezing is generally detrimental to the texture and flavor of most semihard and hard bovine milk cheeses (Luck, 1977), although Mozzarella cheese can be frozen without significant effects on texture (Cervantes et al., 1983) or proteolysis (Chaves et al., 1999). Processed cheeses undergo freezing with minimal effects if frozen rapidly to minimize ice crystal formation, whereas freezing soft Camembert and Brie cheeses resulted in major flavor and texture defects after 1 to 2 mo of frozen storage (Luck, 1977). Port Salut Argentina cheese, a soft fresh cheese from Argentina, showed no significant effects on proteolysis or texture after 2 mo of frozen storage (Verdini and Rubiolo, 2002a,b). Very little is known about the long-term effects of freezing on the quality of caprine milk cheese curd.

Information collected on bovine milk cheeses cannot always be directly related to caprine milk cheeses because of species differences (Haenlein, 2001). Casein is the primary structural component in the cheese matrix; therefore, different distributions of the individual caseins will result in different properties for milk and cheese. Caprine milk contains no or relatively little $\alpha_{\mathrm{S1}^{-}}$ $\mathrm{CN}$, and $\beta$-CN is the major protein in the milk (TziboulaClarke, 2003). In studies of caprine milk containing different levels of $\alpha_{\mathrm{S} 1}{ }^{-} \mathrm{CN}$, the milk containing no $\alpha_{\mathrm{S} 1^{-}}$ $\mathrm{CN}$ had larger micelles, poorer coagulation properties, and formed softer rennet gels (Pirisi et al., 1994; Clark and Sherbon, 2000; Tziboula-Clarke, 2003). The unique internal environment of caprine milk cheeses is an area that has not been studied extensively.

Caprine caseins are hydrolyzed in the same manner as bovine caseins by the enzymes found in cheesemilk (from the mammary gland or added through starter cultures or coagulants) (Trujillo et al., 1995, 1997a,b; Park, 2001). A number of studies have followed the proteolysis of individual and whole caprine casein by specific enzymes in simple systems (Trujillo et al., 1997a,b), whereas others have investigated the proteolysis of whole casein in complex dynamic systems, such 
as aging cheeses (Jin and Park, 1995; Trujillo et al., 1995). Analysis of the protein profiles of several soft, semihard, and hard caprine milk cheeses using PAGE showed variation in the degree of hydrolysis because of different time and storage conditions (Jin and Park, 1996).

The distribution of proteins, their interactions within the cheese matrix, and their degradation with age influence the structure and rheology of the cheese. Rheology quantifies the texture or structure of the food by measuring the food's response to large or small deformations. Although information is becoming available on the proteolysis of caprine milk cheeses, the interactions of proteins within the cheese matrix and the impact of proteolysis on the texture of caprine milk cheeses have not been extensively studied.

The study reported here evaluated the protein distribution and rheology of fresh, soft caprine milk cheese during $28 \mathrm{~d}$ of $4^{\circ} \mathrm{C}$ storage and examined the effects of short- $(2 \mathrm{~d})$ and long-term $(3$ and $6 \mathrm{mo})$ storage at $-20^{\circ} \mathrm{C}$ on the quality of the cheese once thawed and placed in $4^{\circ} \mathrm{C}$ storage.

\section{MATERIALS and METHODS}

\section{Soft Goat Cheese Manufacture}

Grade A soft caprine milk cheeses (crumbled, farmfresh Chevre) were obtained from a Georgia cheese manufacturer. Three batches of cheese were manufactured from pasteurized milk from a pure Nubian herd within a 4-wk period in late summer. Pasteurized milk was rennet-coagulated overnight, and the resulting curd was placed in cheesecloth and hung for $3 \mathrm{~d}$ at $22^{\circ} \mathrm{C}$ to drain. The curd was formed into cheese logs (approximately $225 \mathrm{~g} ; 10.5$ to $11 \mathrm{~cm}$ in length; $5 \mathrm{~cm}$ in diameter), packaged in heat-shrink wrap, and refrigerated at $10^{\circ} \mathrm{C}$ overnight. Multiple logs from each batch were carefully packaged in a cooler with ice packs and immediately shipped overnight to the laboratory in Wyndmoor, PA, where they were placed in either 4 or $-20^{\circ} \mathrm{C}$ storage.

\section{Experimental Design and Treatments}

Cheese logs from each batch of fresh cheese were randomly placed into 1 of 4 treatments ( 3 logs per treatment). Fresh refrigerated control (C) cheeses were placed immediately in $4^{\circ} \mathrm{C}$ storage (without freezing) to age. The rest of the cheese samples were placed into $-20^{\circ} \mathrm{C}$ storage for $2 \mathrm{~d}$ (frozen control, FC), $3 \mathrm{mo}(\mathbf{3 M F})$, or 6 mo $(\mathbf{6 M F})$. After each storage treatment period, frozen samples were removed from the freezer and thawed overnight at $4^{\circ} \mathrm{C}$. The next day was designated $\mathrm{d} 1$ of refrigerated aging. At 1, 14, and $28 \mathrm{~d}$ of aging at $4^{\circ} \mathrm{C}$, one cheese log was selected for testing. Freezing and thawing rates were determined using a thermocouple (Atkins Technical Inc., Gainesville, FL) inserted into the center of a cheese log.

\section{Compositional Analyses}

Proximate analysis was conducted on all cheeses at d 1 of $4^{\circ} \mathrm{C}$ storage. Moisture was measured in triplicate using the forced-draft oven method (AOAC, 1997). Fat was measured in duplicate using the modified Babcock procedure as described by Kosikowski and Mistry (1997). Total nitrogen was measured in duplicate using a nitrogen analyzer (FP-2000, LECO Corp., St. Joseph, $\mathrm{MI})$, with the combustion chamber at $1050^{\circ} \mathrm{C}$. Protein content was calculated using $\mathrm{N} \times 6.38$. Salt levels were determined on duplicate samples using the Quant-Tab chloride titrations (Environmental Test Systems, Inc., Elkhart, IN). The $\mathrm{pH}$ (based on 6 observations) was determined for each cheese log before rheology testing.

\section{Protein Profile and Proteolytic Analysis}

Water-soluble proteins were extracted from cheeses tested after 1 and $28 \mathrm{~d}$ of aging at $4^{\circ} \mathrm{C}$ using a modified process based on the method described by Tunick et al. (1995). Five milliliters of Tris-SDS-EDTA-dithiothreitol buffer ( $\mathrm{pH} 8$ ) was added to $2 \mathrm{~g}$ of cheese and vortexed (Scientific Industries, Inc., Bohemia, NY) for $2 \mathrm{~min}$. Five milliliters of 7\% SDS in Tris-EDTA buffer was added, and mixture was vortexed for $1 \mathrm{~min}$. Two milliliters of dithiothreitol was added, vortexed to mix, and chilled on ice for a minimum of 15 min. Solution was centrifuged (Sorvall RC-5B, Kendro, Asheville, NC) at $39,000 \times g$, at $4^{\circ} \mathrm{C}$ for $60 \mathrm{~min}$. The supernatant was filtered to remove lipid, lyophilized, and stored at $-35^{\circ} \mathrm{C}$.

Lyophilized samples were prepared for SDS-PAGE as described by Tunick et al. (1995). Protein extracts were separated on $20 \%$ homogeneous ultra-thin precast polyacrylamide gels using the PhastSystem (Pharmacia Biotech, Piscataway, NJ). Protein bands were stained with Coomassie Blue. Gels were scanned and analyzed using the SI model 375A personal densitometer with ImageQuant software (Molecular Dynamics, Sunnyvale, CA). Two lines were placed through each lane; the software generated density graphs and calculated the area under each peak; means were based on 6 lines per treatment per aging time. Protein bands and associated peaks were identified as $\alpha_{\mathrm{s} 2}-\mathrm{CN}$ and $\beta$ CN. A bovine skim milk reference was used to determine the molecular mass ranges of 22 to $18 \mathrm{kDa}$ (migrating ahead of $\beta$-CN and behind $\beta$-LG), 18 to $15 \mathrm{kDa}$ (migrating ahead of $\beta$-LG and behind $\alpha-\mathrm{LA}$ ), and 14 to 
$10 \mathrm{kDa}$ (migrating ahead of $\alpha$-LA and before the buffer strip contact point; peptides smaller than $10 \mathrm{kDa}$ migrated off the gels). The molecular mass ranges contained multiple peptides, some currently unidentified. Comparison of protein and peptide distributions at $\mathrm{d} 1$ and 28 were used to determine the degree of proteolysis.

\section{Rheological Properties Analyses}

Rheological properties of all cheese samples were tested after 1,14 , or $28 \mathrm{~d}$ of $4^{\circ} \mathrm{C}$ storage. All cheese logs were warmed to room temperature $\left(22 \pm 1^{\circ} \mathrm{C}\right)$ before samples were taken from the interior of the log.

Texture profile analysis. Texture profile analysis (TPA) was conducted according to Tunick et al. (1995). Cylindrical plugs (approximately $14.5 \mathrm{~mm}$ in diameter and height) were placed into a Universal Testing Machine (model SM-25-155, Material Testing Products Systems Corp., Eden Prairie, MN) and compressed by $75 \%$ twice using a crosshead speed of $100 \mathrm{~mm} / \mathrm{min}$. The hardness, cohesiveness, and springiness of the cheeses were measured from the force-time curves and used to calculate chewiness (product of hardness $\times$ cohesiveness $\times$ springiness). Four plugs were tested per sample.

Small amplitude oscillatory shear analysis. Viscoelastic properties of the cheeses were obtained according to the procedure described by Tunick et al. (1995). Cheese discs (diameter, $25.4 \mathrm{~mm}$; height, 4 to $5 \mathrm{~mm}$ ) were glued to parallel plates and placed in a Dynamic analyzer (model RDA-700, Rheometrics Scientific, Piscataway, NJ). The linear viscoelastic range of each cheese was determined by a strain sweep. Frequency sweeps ( 0.1 to $100 \mathrm{rad} / \mathrm{s}$ ) were conducted at $0.8 \%$ strain, and elastic $\left(\mathbf{G}^{\prime}\right)$ and viscous $\left(\mathbf{G}^{\prime \prime}\right)$ moduli were used by the instrument's software to calculate complex viscosity (eta*). Tests were conducted in triplicate.

\section{Statistical Analyses}

Experimental data were analyzed using statistical software (SAS Institute, 2001). Rheology data collected from 4 storage treatments and 3 aging times were used in a $4 \times 3$ factorial arrangement in 3 complete randomized blocks. Proteolytic data collected from 4 storage treatments and 2 aging times were used in a $4 \times 2$ factorial arrangement in 3 complete randomized complete blocks, each block consisting of cheese logs from the same batch. The GLM procedure was used to calculate the ANOVA using the following classes: batch, storage treatment, aging time, and treatment $\times$ aging interaction. The mean square error from the ANOVA table calculated for each casein or protein distribution and each rheological property was used in the Bonferroni $t$-test to compare means; mean differences were stated as significant at the $5 \%$ level $(P<0.05)$.

\section{RESULTS AND DISCUSSION}

The cheese logs placed in the $-20^{\circ} \mathrm{C}$ freezer illustrated a typical freezing pattern. The initial chilling $\left(-0.14^{\circ} \mathrm{C} / \mathrm{min}\right)$ reduced the core temperature to the freezing point of the cheese curd $\left(-2.5^{\circ} \mathrm{C}\right)$ within 45 min. Under the conditions of this study, the moisture in the cheese curd required approximately $120 \mathrm{~min}$ to undergo phase change and reorganize into ice crystals before the temperature continued to decrease at $-0.11^{\circ} \mathrm{C} / \mathrm{min}$ to $-15^{\circ} \mathrm{C}$. As the temperature of the sample neared the storage temperature of $-20^{\circ} \mathrm{C}$, the rate of cooling slowed to approximately $-0.03^{\circ} \mathrm{C} / \mathrm{min}$. Although this procedure is not flash freezing, which would result in the formation of the smallest of ice crystals, it is similar to conditions that the industry may use to freeze cheese curds. The lack of free liquid when the samples were thawed indicated that water was not drawn out of the cheese matrix to form large ice crystals and suggested that the ice crystals that formed within the cheese matrix were not particularly large. The freezing protocol used in this study was adequate to determine the effect of freezing on the rheology of the cheese. Further studies would be needed to identify optimal freezing rates and conditions suitable for commercial applications.

Previous research into the effect of freezing on cheese quality reports mixed results. Luck (1977) reported that freezing cheese had variable effects on flavor, texture (sensory), and appearance. The best results were obtained when cheeses were chilled below $0^{\circ} \mathrm{C}$ but stored above the actual freezing point of the cheese, thereby avoiding damage caused by the formation of ice crystals. Storage below the freezing point of the specific cheese typically results in crumbly or mealy cheese texture. Processed cheeses show minimal sensory effects if the cheeses are frozen rapidly to minimize ice crystal formation, whereas freezing soft Camembert and Brie cheeses at $-10^{\circ} \mathrm{C}$ resulted in major flavor and texture defects after 1 to 2 mo of storage (Luck, 1977).

Cheese logs were placed in $4^{\circ} \mathrm{C}$ storage to thaw overnight and were completely thawed by the time rheology tests were performed the next day. Thawing profile indicated that the largest warming phase $\left(0.25^{\circ} \mathrm{C} / \mathrm{min}\right)$ occurred within the first hour after being removed from the freezer and placed in $4^{\circ} \mathrm{C}$ storage; core temperature increased from $-20.0^{\circ} \mathrm{C}$ to approximately $-8.1^{\circ} \mathrm{C}$. Outside of a phase change $\left(0.01^{\circ} \mathrm{C} / \mathrm{min}\right)$ between 3.5 and $6.0 \mathrm{~h}$, the core temperature of the cheese logs warmed at 0.02 to $0.03^{\circ} \mathrm{C} / \mathrm{min}$ during the first $9 \mathrm{~h}$ and reached $4^{\circ} \mathrm{C}$ by $12 \mathrm{~h}$.

The $\mathrm{pH}$ of the cheese logs remained stable (varied from 4.05 to 4.14) throughout the study, and was not affected by any length of freezing or a $28-\mathrm{d}$ refrigerated 
Table 1. Distribution means $(n=6)$ of the water-soluble proteins extracted from soft caprine milk cheeses after different storage treatments and then aged at $4^{\circ} \mathrm{C}$ for 1 or $28 \mathrm{~d}$. Proteins were separated on $20 \%$ homogeneous ultra-thin gels using SDS-PAGE and stained. The distribution of proteins in each lane was quantified using a densitometer.

\begin{tabular}{|c|c|c|c|c|c|c|c|c|c|c|}
\hline \multirow[b]{3}{*}{ Milk proteins } & & & \multicolumn{8}{|c|}{ Treatment $^{1}$} \\
\hline & \multicolumn{2}{|c|}{ Milk references } & \multicolumn{2}{|c|}{$\mathrm{C}$} & \multicolumn{2}{|c|}{$\mathrm{FC}$} & \multicolumn{2}{|c|}{$3 \mathrm{MF}$} & \multicolumn{2}{|c|}{$6 \mathrm{MF}$} \\
\hline & Bovine & Caprine & $1 \mathrm{~d}$ & $28 \mathrm{~d}$ & $1 \mathrm{~d}$ & $28 \mathrm{~d}$ & $1 \mathrm{~d}$ & $28 \mathrm{~d}$ & $1 \mathrm{~d}$ & $28 \mathrm{~d}$ \\
\hline & & & & & $-(\%$ & & & & & \\
\hline $\begin{array}{l}\text { Casein } \\
\alpha_{\mathrm{S} 2}-\mathrm{CN}\end{array}$ & \multicolumn{9}{|c|}{ Casein } & $12.4^{\mathrm{a}}$ \\
\hline$\alpha_{\mathrm{S} 1}-\mathrm{CN}$ & 29.1 & 0.0 & 0.0 & 0.0 & 0.0 & 0.0 & 0.0 & 0.0 & 0.0 & 0.0 \\
\hline$\beta-\mathrm{CN}$ & 32.1 & 60.9 & $55.7^{\mathrm{ab}}$ & $53.4^{\mathrm{b}}$ & $58.6^{\mathrm{a}}$ & $57.8^{\mathrm{ab}}$ & $57.9^{\mathrm{ab}}$ & $54.9^{\mathrm{ab}}$ & $59.5^{\mathrm{a}}$ & $57.3^{\mathrm{ab}}$ \\
\hline$\kappa-\mathrm{CN}$ & 5.2 & 6.4 & 0.0 & 0.0 & 0.0 & 0.0 & 0.0 & 0.0 & 0.0 & 0.0 \\
\hline \multicolumn{11}{|l|}{ Casein fragments } \\
\hline 22 to $18.5 \mathrm{kDa}$ & 2.5 & 2.4 & $10.0^{\mathrm{ab}}$ & $10.9^{\mathrm{a}}$ & $9.2^{\mathrm{bc}}$ & $8.2^{\mathrm{cd}}$ & $8.0^{\mathrm{cd}}$ & $9.1^{\mathrm{bc}}$ & $7.5^{\mathrm{d}}$ & $8.9^{\mathrm{bcd}}$ \\
\hline 18 to $15 \mathrm{kDa}^{2}$ & 1.7 & $<1$ & $14.3^{\mathrm{a}}$ & $14.0^{\mathrm{a}}$ & $11.8^{\mathrm{ab}}$ & $11.1^{\mathrm{b}}$ & $10.9^{\mathrm{b}}$ & $11.1^{\mathrm{b}}$ & $10.1^{b}$ & $11.0^{\mathrm{b}}$ \\
\hline 14 to $10 \mathrm{kDa}$ & 2.3 & 1.7 & $7.0^{\mathrm{ab}}$ & $8.8^{\mathrm{a}}$ & $7.1^{\mathrm{ab}}$ & $8.0^{\mathrm{ab}}$ & $7.0^{\mathrm{ab}}$ & $9.3^{\mathrm{a}}$ & $5.1^{\mathrm{b}}$ & $5.7^{\mathrm{b}}$ \\
\hline
\end{tabular}

storage period. Because the cheese curds were below the isoelectric point of the casein ( $\mathrm{pH} 4.6)$, the problems associated with decreasing $\mathrm{pH}$ noted in cheeses in $\mathrm{pH}$ range of 5 to 5.5 were not a factor in this study. In addition, because of the $\mathrm{pH}$ of the cheese curd, the charges and interactions among the proteins and their peptides will be different from cheeses at higher $\mathrm{pH}$ and require additional study.

\section{Composition}

Cheese composition did not vary with storage treatments. Overall means for the soft cheeses were $58.4 \pm$ $1.5 \%$ moisture, $15.6 \pm 1.4 \%$ protein, $22.9 \pm 1.6 \%$ fat, and $2.1 \pm 0.4 \%$ salt. This is similar to the $58 \%$ moisture, $15 \%$ protein, and $21 \%$ fat previously reported for a rennet-set brined, soft caprine milk cheese (Martin-Hernandez et al., 1990).

\section{Protein Profiles and Proteolysis}

The slight changes in protein and peptide distributions found in soft caprine milk cheeses undergoing different storage treatments, and over a 28-d aging time are summarized in Table 1 . It was noted that $\alpha_{\mathrm{S} 1}-\mathrm{CN}$ was not detected (by SDS-PAGE) in the cheese milk from the commercial dairy. Analysis of protein distribution showed a casein distribution of 1:4:4:1 for $\alpha_{\mathrm{S} 2}-\mathrm{CN}$ : $\alpha_{\mathrm{S} 1}-\mathrm{CN}: \beta$-CN: $\kappa$-CN in the bovine milk reference, and the ratio of 1:7:1 for $\alpha_{\mathrm{S}_{2}} \mathrm{CN}$ : $\beta$-CN: $\kappa$-CN in the caprine milk reference.
Only slight changes in the protein distribution were noted among the different storage treatments, indicating that minimal proteolysis occurred during this study (Table 1). The concentrations of $\beta-\mathrm{CN}$ and $\alpha_{\mathrm{S} 2}-\mathrm{CN}$ did not vary significantly among storage treatments or over $28 \mathrm{~d}$ of aging at $4^{\circ} \mathrm{C}$. The distribution of the peptides showed more variation. The $\mathrm{C}$ cheeses consistently had slightly more peptides in the 22 to 18.5 and 18 to 15 $\mathrm{kDa}$ ranges than did the $3 \mathrm{MF}$ and $6 \mathrm{MF}$ cheeses. Based on the proteolysis research reported by Trujillo et al. (1995, 1997a,b) and shown on SDS-PAGE, the 22-to$18.5-\mathrm{kDa}$ range would contain most of the larger $\beta-\mathrm{CN}$ peptides such as $\beta$-CN (f1-190) and $\beta$-CN (f29-207). The $\kappa$-CN fragment (f1-105) would be the predominant peptide in the 18-to-15-kDa range, whereas the smaller $\beta$ CN fragments, such as $\beta$-CN (f106-207) and $\beta$-CN (f108207 ), and any $\alpha_{\mathrm{S} 2^{-}} \mathrm{CN}$ generated peptides would be in the 14-to-10-kDa range. Cheese aging is usually accompanied by an increase in peptide levels, as proteins are hydrolyzed into smaller peptides and amino acids. Although the levels of intact proteins tended to decrease over $28 \mathrm{~d}$ of refrigerated storage, the decrease was not significant and indicated a slow rate of proteolysis in the cheeses. With the recent advances in instrumentation, future studies will be able to identify the peptides smaller than $10 \mathrm{kDa}$ that were lost using SDS-PAGE, and confirm the identity of many of the peptides within the molecular mass ranges that are currently unresolved.

Within the storage treatments, protein-peptide levels were not significantly different between $\mathrm{d} 1$ and 28 . The 
results reported here are similar to those reported by Martin-Hernandez et al. (1990), in which no significant changes in $\alpha_{\mathrm{S}_{2}} \mathrm{CN}$ and $\beta$-CN concentrations were found in soft goat cheese over the first $15 \mathrm{~d}$ of storage at 0 to $4^{\circ} \mathrm{C}$, and by Jin and Park (1996) in which no significant hydrolysis of $\alpha_{\mathrm{S} 2}$-CN occurred in soft goat cheese over 24 wk of storage. Jin and Park (1996) used SDS-PAGE to show that the protein profile of soft goat cheese changed significantly over 24 wk of storage and between storage temperatures of 4,13 , and $22^{\circ} \mathrm{C}$. The major change between the 0 and 8 wk samples was the increase in the $\beta$-CN (f29-207) band.

\section{Rheological Properties}

In this study, frozen and refrigerated storage had little effect on the $\mathrm{pH}$ of the curd and the proteolysis of the caseins. Therefore, changes in rheology were not due to the breakdown of the protein matrix of the cheese or changes in the solubility of the matrix components.

Texture profile analysis, which uses large destructive shear to compress the cheese matrix, measures the cheese's response to the deformation (Figure 1) and gives insight into overall strength and construction of the cheese (Tunick, 2000). The cheese curds were very fragile and did not hold together well when worked, which was reflected in the low TPA hardness, cohesiveness, and chewiness values. When freezing effects were evaluated at $1 \mathrm{~d}$ of $4^{\circ} \mathrm{C}$ aging, cheeses frozen for only $2 \mathrm{~d}$ (FC) were softer and less chewy than the cheeses stored at $-20^{\circ} \mathrm{C}$ for longer periods ( $3 \mathrm{MF}$ and $6 \mathrm{MF}$ ); the $6 \mathrm{MF}$ cheeses tended to have the highest values for chewiness and cohesiveness. With aging, FC cheeses increased in hardness and chewiness to levels comparable to the other cheeses. The TPA properties of C, 3MF, and $6 \mathrm{MF}$ cheeses did not change significantly over 28 $\mathrm{d}$ of aging. This suggests that short-term freezing altered the strength of the cheese matrix in some manner. The springiness of the soft cheeses did not vary significantly throughout the study (ranged from 9.9 to 10.7 $\mathrm{mm}$ ) and was not affected by freezing or aging; springiness values are not reported. The TPA values reported in this study are higher than in the study of MartinHernandez et al. (1990), in which salted soft goat cheese had a hardness (measured using a universal testing machine) of 0.32 to $0.35 \mathrm{~N}$ over the first $15 \mathrm{~d}$ of storage at 0 to $4^{\circ} \mathrm{C}$, and 0.36 to $0.37 \mathrm{~N}$ after 4 mo of frozen storage $\left(-20^{\circ} \mathrm{C}\right)$.

Small amplitude oscillatory strain analysis, which uses oscillatory motion at low strains to stretch internal bonds within the cheese, measures the cheeses' response to small-scale deformation (Figure 2) and gives insight into the interactions between the internal bonds of the cheese matrix (Tunick, 2000). The low values for a)

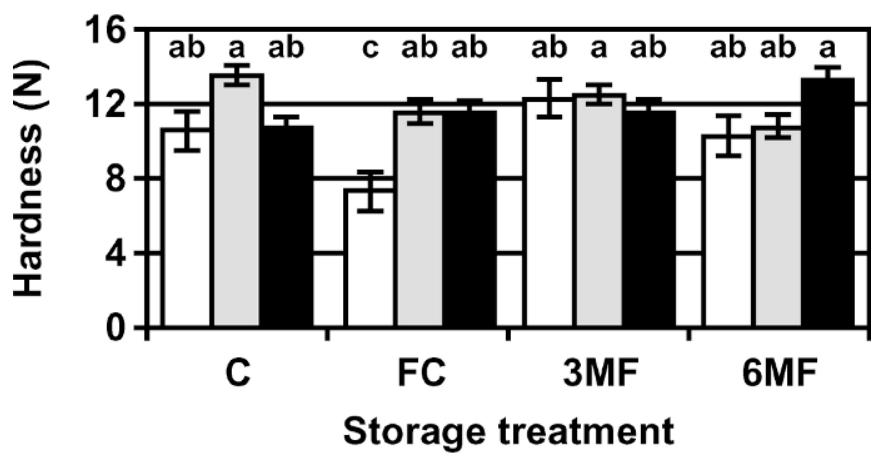

b)

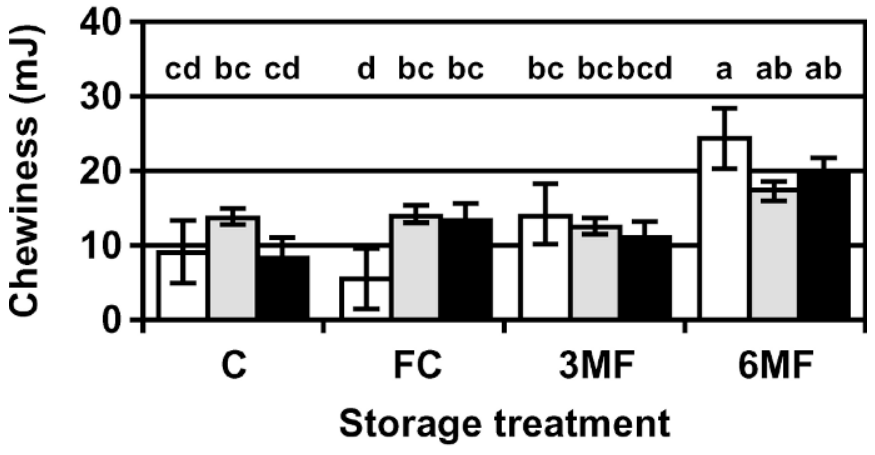

c)

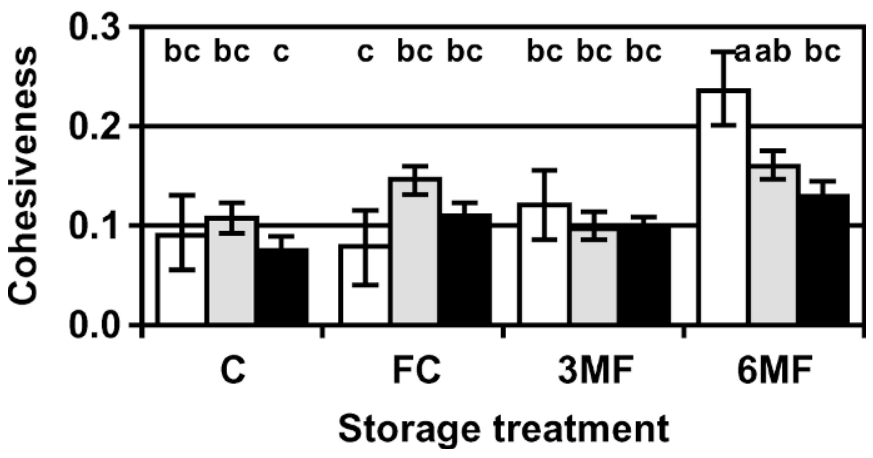

Figure 1. Summary of texture profile analysis rheological properties, a) hardness, b) chewiness, and c) cohesiveness, of soft caprine milk cheeses under different storage treatments $(C=$ fresh control, no freezing; $\mathrm{FC}=$ frozen control, frozen for $2 \mathrm{~d} ; 3 \mathrm{MF}=$ frozen for 3 $\mathrm{mo}$; and $6 \mathrm{MF}=$ frozen for $6 \mathrm{mo})$ and over $28 \mathrm{~d}$ of aging at $4^{\circ} \mathrm{C}(0 \mathrm{~d}=$ white; $14 \mathrm{~d}=$ gray; $28 \mathrm{~d}=$ black). ${ }^{\mathrm{a}, \mathrm{b}, \mathrm{c}}$ Columns with the same letter are not significantly different $(P<0.05)$. Bonferroni $t$-test used mean square error terms from ANOVA tables; hardness = 11.6; cohesiveness $=0.003 ;$ chewiness $=36.5 ; \mathrm{n}=12$. Standard error bars are shown.

the viscoelastic properties indicated that internal bonds holding the cheese matrix together were very weak. The $\mathrm{C}, 3 \mathrm{MF}$, and $6 \mathrm{MF}$ cheeses had similar and stable viscoelastic properties throughout the study, although the $6 \mathrm{MF}$ cheeses tended to have the highest values. The viscoelastic properties of FC cheese tended to de- 
a)

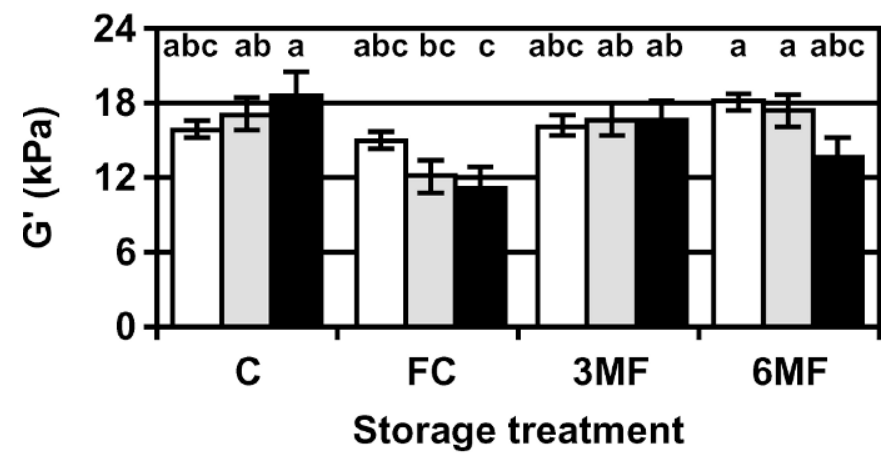

b)

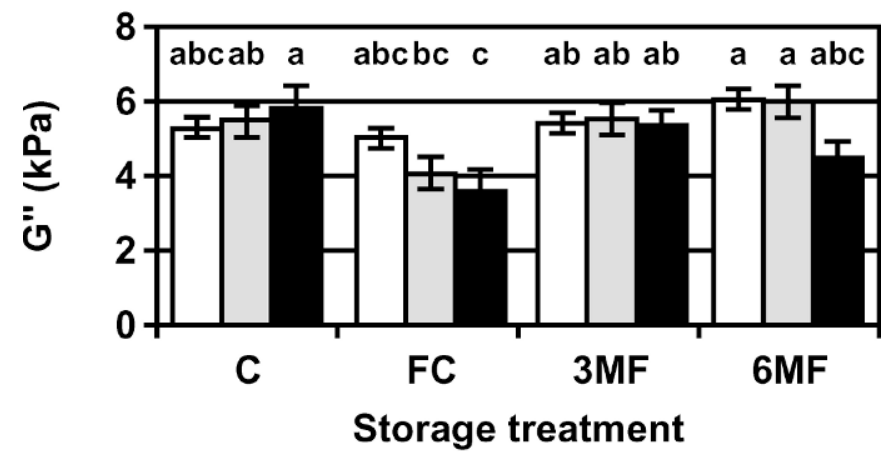

c)

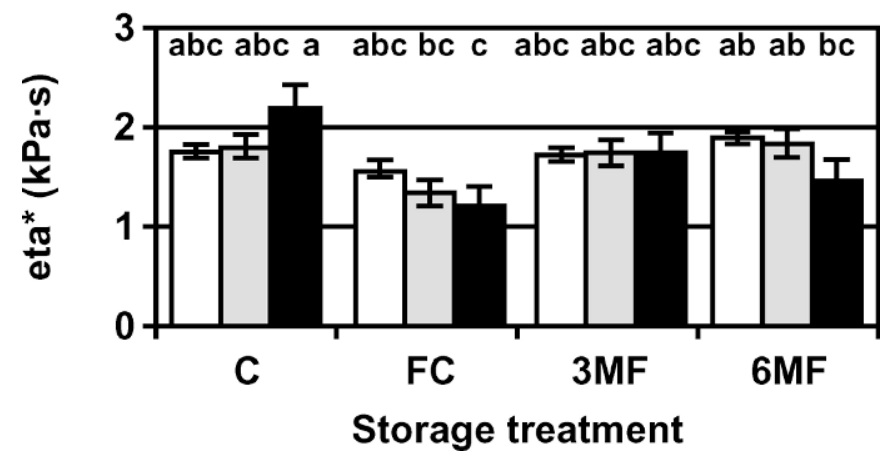

Figure 2. Summary of viscoelastic properties, a) G', elastic modulus; b) G", viscous modulus; and c) eta*, complex viscosity, of soft caprine milk cheeses under different storage treatments $(\mathrm{C}=$ fresh control, no freezing; $\mathrm{FC}=$ frozen control, frozen for $2 \mathrm{~d} ; 3 \mathrm{MF}=$ frozen for $3 \mathrm{mo}$; and $6 \mathrm{MF}$ = frozen for $6 \mathrm{mo}$ ) and over $28 \mathrm{~d}$ of aging at $4^{\circ} \mathrm{C}$ ( $0 \mathrm{~d}=$ white; $14 \mathrm{~d}$ = gray; $28 \mathrm{~d}=$ black). ${ }^{\mathrm{a}, \mathrm{b}, \mathrm{c}}$ Columns with the same letter are not significantly different $(P<0.05)$. Bonferroni $t$-test used mean square error terms from ANOVA tables; $\mathrm{G}^{\prime}=10.23, \mathrm{G}^{\prime \prime}=1.08$; eta* $=0.14 ; \mathrm{n}=9$. Standard error bars are shown.

crease over $28 \mathrm{~d}$ of refrigerated aging to a point where they were significantly lower than the $\mathrm{C}$ cheeses. This supports the assumption that short-term freezing altered something in the cheese matrix.

Overall, freezing had little effect on the rheological properties. This agrees with previous soft cheese re- search. Martin-Hernandez et al. (1990) reported no difference in the hardness $(0.35$ to $0.37 \mathrm{~kg} / \mathrm{g})$ of rennetset brine-salted caprine milk soft cheese after 4 mo of frozen storage. Luck (1977) reported that bovine milk processed cheese could be stored at $-10^{\circ} \mathrm{C}$ for up to 5 mo without quality degradation if the formation of large ice crystals is prevented. Verdini and Rubiolo (2002a,b) reported that 2 mo of frozen storage had no effect on the rheological properties of bovine milk Port Salut Argentina (soft) cheese.

It has been suggested that freezing of cheese curd results in the formation of ice crystals that disrupt the casein network (Luck, 1977). It is possible that after only $2 \mathrm{~d}$ of freezing, a small amount of bound water was still present within the cheese matrix and existed in a concentrated solute form that disrupted casein interactions and structure. After 3 and 6 mo of $-20^{\circ} \mathrm{C}$ storage, that water finally froze and the proteins were able to form stable structures around the ice crystals.

The lack of change in the viscoelastic properties of the $\mathrm{C}, 3 \mathrm{MF}$, and $6 \mathrm{MF}$ soft cheeses supports the use of freezing to maintain the textural quality of the soft cheese in long-term storage. It also demonstrated that any structural defect caused by freezing was not detectable at low strains and required the larger forces used by TPA to give a measurable response. The TPA rheological properties obtained on $\mathrm{d} 1$ had the largest standard error range and showed the most changes, which suggested that the TPA instrument (as programmed for this study) might have been at the lower limit of its sensitivity. It also points out the need for more comparison data on the rheological properties of caprine milk cheese.

The protein matrix of caprine milk cheese is comprised of intact $\beta$-CN and $\alpha_{\mathrm{S}^{2}} \mathrm{CN}$, as well as a wide assortment of casein fragments. The $\beta-\mathrm{CN}$, the most hydrophobic of the caseins, is sensitive to environmental conditions and tends to self-associate, whereas $\alpha_{\mathrm{S}^{-}}$ $\mathrm{CN}$, the most hydrophilic of the caseins, has 4 distinct domains (2 hydrophobic and 2 hydrophilic) and is very sensitive to calcium ions (Farrell et al., 2004). In studies of caprine milk containing different concentrations of

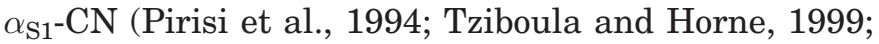
Clark and Sherbon, 2000), milks that contain no $\alpha_{\mathrm{S} 1}-\mathrm{CN}$ formed the largest micelles, demonstrated poor rennet coagulation properties, which led to higher fat loss and lower yields during cheese making, and resulted in softer milk gels (Remeuf, 1992; Pirisi et al., 1994). The caprine milk used in this study did not contain $\alpha_{\mathrm{S} 1}-\mathrm{CN}$; therefore, the texture of the cheese curd was expected to be soft and the internal bonds to be weak. The fact that this particular soft cheese has a $\mathrm{pH}$ below the isoelectric point of casein raises other questions about caprine caseins, because most of the research on caprine 
caseins has been conducted at $\mathrm{pH}$ above the isoelectric point.

\section{CONCLUSIONS}

Overall, the caprine milk soft cheeses were very fragile and freezing had minimal impact on the rheology of the cheese. Sodium dodecyl sulfate-PAGE of fresh soft cheeses showed minimal proteolysis, with freezing having little impact on protein breakdown. Rheology techniques were capable of measuring the very low values for the TPA and small amplitude oscillatory strain properties in soft caprine milk cheeses, and showed a few slight changes in the cheese structure due to freezing and refrigerated aging. Further study is required to determine if these textural changes are detectable by the consumer.

When comparing storage treatments $\left(4^{\circ} \mathrm{C}\right.$ storage only vs. frozen storage), cheeses that had been frozen and then immediately thawed showed the most change in rheological properties. This suggests that a minimum holding time maybe required, allowing the curd to adjust to the ice crystals within the cheese matrix and possible freeze concentration effects. The freezing of caprine milk soft cheese has minimal effects on the cheese rheology and suggests a way to extend the shelf life and expand the availability of the soft cheeses to a year-round distribution.

\section{ACKNOWLEDGMENTS}

Authors thank James Shieh for compositional and viscoelastic data, John Phillips for guidance with the statistical analysis, Michael Kozempel for his contribution to the phase change discussion, and Maryanne Wildermuth for her help with the electrophoresis. Support from the USDA Southern Region Sustainable Agriculture Research and Education program and the USDA 1890 Institutional Capacity Building are gratefully acknowledged.

\section{REFERENCES}

AOAC. 1997. Official Methods of Analysis. 16th ed. AOAC International, Gaithersburg, MD.

Cervantes, M. A., D. B. Lund, and N. F. Olson. 1983. Effects of salt concentration and freezing on Mozzarella cheese texture. J. Dairy Sci. 66:204-213.
Chaves, W., H. Viotto, and C. R. E. Grosso. 1999. Proteolysis and functional properties of Mozzarella cheese as affected by refrigerated storage. J. Food Sci. 64:202-205.

Clark, S., and J. W. Sherbon. 2000. Alpha s1-casein, milk composition and coagulation properties of goat milk. Small Rumin. Res. 38:123-134.

Farrell, H. M., Jr., R. Jimenez-Flores, G. T. Bleck, E. M. Brown, J. E. Butler, L. K. Creamer, C. L. Hicks, C. M. Hollar, K. F. NgKwai-Hang, and H. E. Swaisgood. 2004. Nomenclature of the proteins of cow's milk-Sixth revision. J. Dairy Sci. 87:1641-1674.

Haenlein, G. F. W. 2001. Past, present, and future perspectives of small ruminant dairy research. J. Dairy Sci. 84:2097-2115.

Jin, Y. K., and Y. W. Park. 1995. Effects of aging time and temperature on proteolysis of commercial goat milk cheeses produced in the United States. J. Dairy Sci. 78:2598-2608.

Jin, Y. K., and Y. W. Park. 1996. SDS-PAGE of proteins in goat milk cheeses ripened under different conditions. J. Food Sci. 61:490-494.

Kosikowski, F. V., and V. V. Mistry. 1997. Analysis. Pages 211-212 in Cheese and Fermented Milk Foods. Vol. 2. Procedures and Analysis. 3rd ed. F. V. Kosikowski, LLC, Westport, CT.

Luck, H. 1977. Preservation of cheese and perishable dairy products by freezing. S. Afr. J. Dairy Technol. 9:127-132.

Martin-Hernandez, C., M. Juarez, M. Ramos, and P. Martin-Alvarez. 1990. Effects of freezing and frozen storage on the physicochemical and sensory characteristics of four types of goat's cheese. Z. Lebensm. Unters. Forsch. 190:325-330.

Park, Y. W. 2001. Proteolysis and lipolysis of goat milk cheese. J. Dairy Sci. 84(E. Suppl.):E84-E92.

Pirisi, A., O. Colin, F. Laurent, J. Scher, and M. Parmentier. 1994. Comparison of milk composition, cheesemaking properties and textural characteristics of the cheese from two groups of goats with high or low rate of $\alpha_{\mathrm{s} 1}$-casein synthesis. Int. Dairy J. 4:329-345.

Remeuf, F. 1992. Physico-chemical properties of goat milk in relation to processing characteristics. Pages $98-111$ in National Symposium on Dairy Goat Production and Marketing, Langston University, Langston, OK.

SAS Institute. 2001. SAS System for Windows, Version 8.02. SAS Institute Inc., Cary, NC.

Trujillo, A. J., B. Guamis, and C. Carretero. 1995. Proteolysis of goat $\beta$-casein by calf rennet under various factors affecting the cheese ripening process. J. Agric. Food Chem. 43:1472-1478.

Trujillo, A. J., B. Guamis, and C. Carretero. 1997a. Proteolysis of goat casein by calf rennet. Int. Dairy J. 7:579-588.

Trujillo, A. J., B. Guamis, and C. Carretero. 1997b. Hydrolysis of caprine $\beta$-casein by plasmin. J. Dairy Sci. 80:2258-2263.

Tunick, M. H. 2000. Rheology of dairy foods that gel, stretch, and fracture. J. Dairy Sci. 83:1892-1898.

Tunick, M. H., E. L. Malin, P. W. Smith, and V. H. Holsinger. 1995. Effects of skim milk homogenization on proteolysis and rheology of Mozzarella cheese. Int. Dairy J. 5:483-491.

Tziboula-Clarke, A. 2003. Goat milk. Pages 1270-1279 in Encyclopedia of Dairy Sciences. J. W. Fuquay and P. F. Fox, ed. Academic Press, San Diego, CA.

Tziboula, A., and D. S. Horne. 1999. The role of $\alpha_{\mathrm{s} 1}$-casein in the structure of caprine casein micelles. Int. Dairy J. 9:173-178.

Verdini, R. A., and A. C. Rubiolo. 2002a. Effect of frozen storage time on the proteolysis of soft cheeses studied by principal component analysis of proteolytic profiles. J. Food Sci. 67:963-967.

Verdini, R. A., and A. C. Rubiolo. 2002b. Texture changes during the ripening of Port Salut Argentino cheese in 2 sampling zones. J. Food Sci. 67:1808-1813. 